\title{
Integration and Innovation Determinants of Modern Mining Higher Education Development
}

\author{
Jürgen Kretschmann ${ }^{1}$, Inna Pevneva ${ }^{2}$, Svetlana Ivanova $^{3}$,Elena Sant'eva $^{3}$, and Maxim \\ Bakanov $^{3}$ \\ ${ }^{1}$ Technische Hochschule Georg Agricola, Centre for Drive and Lifting Technology ZAFT, Bochum, \\ Germany \\ ${ }^{2}$ T.F. Gorbachev Kuzbass state technical university, ul. Vesennaya 28, Kemerovo, Russia \\ ${ }^{3}$ Kemerovo State University, 650000, 6 Krasnaya st., Kemerovo, Russia
}

\begin{abstract}
The development prospects of Russian industry are defined as a transition to the post-industrial stage of development. It is characterized, on the one hand, by a high share of deep processing of raw materials, mass production of digital products; on the other hand - by the development of a "knowledge economy" and the emergence of technical universities in the place of flagships for innovative development. At present, the integration trend of industry and higher engineering education is deepening, globalization of national educational complexes is ongoing, and international university cooperation is developing. All this has become a part of the production process and education globalization. The university community cannot stand aloof from the all-pervasive process of globalization of social-and-economic relations, the formation of their planetary model. Universities of leading countries are actively integrating both into international educational and business interactions. The entry of Russian corporations into the world markets means the transfer of global requirements for personnel quality training. Special competencies in the post-industrial economy are becoming the determining factor of competitiveness. This is especially true for mining engineers, whose university training in Russia is also carried out in the context of integration of national higher education system in the global educational market.
\end{abstract}

\section{Introduction}

Today the scientific community is actively discussing the Russian economy advantages necessary for innovative development - a relatively high level of urbanization, a significant scientific and industrial heritage of the USSR, including developed raw materials sector, and a relative modern system of training engineering personnel. By transmitting the imperatives that the Bologna process induced Russian higher education to train mining engineers, the following tasks can be identified [1-2]:

1. Not to lengthen the period of study at the university; reduce the state financial costs for students, while maintaining the quality of training. This plays a special role for higher mining education, the quality of which determines, on the one hand, the competitiveness of the national raw materials complex, and on the other, labor safety. 
2. To ensure the level of qualification of graduates, allowing to immediately get involved in the production process and the management of complex technological processes of a modern mining enterprise.

3. To integrate the Russian system of mining engineers training in the international labor market aiming at reproduction of modern personnel in the oil and gas, coal mining industries, ferrous and non-ferrous metallurgy, power producing and petroleum and coal chemistry.

4. To provide the opportunity for graduates improve their qualifications and possible employment in any country, including the European Union, through a system of grants for training students from other countries.

5. To ensure the compatibility and comparability of national systems of higher mining education and establish uniform educational standards.

In addition to these tasks, the Bologna Agreements established clear requirements for modern higher education in the context of globalization, according to which we observe the following changes in it [3-4]. Firstly, the introduction of the European Credit Transfer System - ECTS has begun in Russia. Secondly, in the near future, university graduates will have to receive the European Diploma Supplement, which reflects information about the student's entire educational process, as well as the presence of a literal assessment of student knowledge from A (excellent) to F (unsatisfactory). Thirdly, we are witnessing a policy of international openness of technical universities, which should result in an increase in the mobility of students and teaching personnel. Finally, this is the introduction of a point-rating system for assessing knowledge and independent work of students.

However, the international community of the raw materials producers, in which the barriers to the international movement of products and investments are reduced every year, and the international migration of specialists is accelerated, puts the main requirements for modern higher education forward.

\section{Materials and Methods}

Many graduates of modern technical universities, going on an internship to Germany, France, the UK, China, fall into a cross-cultural and educational multi-platform community in which there are the most modern and traditional methods of knowledge transfer, different educational regulatory frameworks, corporate ethics standards and social responsibility.

Russian higher school representatives, including mining universities, are now at the start of integration into the global educational community. However, a serious obstacle to this integration is the low position of Russian universities in international rankings. So, for example, not a single Russian university fell into the international ranking "Top 200 World Universities of the Times higher education-QS rating" in 2012-2019, the first places in which are occupied by universities of the USA and Great Britain. This list includes, for example, universities of China, Singapore, Australia, Belgium, South Korea, etc. [5]

Another difficulty in integrating Russian mining education was the limited recognition of diplomas of domestic universities in employment abroad. Russian graduates have to confirm the level of their knowledge and skills through the system of additional tests. At the same time, the level of training of specialists with higher education, including mining engineers, in Russia is gradually decreasing. One of the reasons for this is the lack of motivation to acquire knowledge and readiness of applicants to study at mining university.

In fact, Russian higher mining education will have to overcome the disunity of universities - providers of educational services, and enterprises - educational customers, and the state - the owner of institutes and universities, and go through several levels of globalization of the educational sphere. Russian engineering universities today go through the following set of integration processes: 
- At the educational and methodological level of a particular university, the introduction of international experience in mining engineering activities in the educational process during project and case studies, high interaction of teachers and students is expanding;

- At the university level, the adaptation of curriculum and educational programs to the needs of specific enterprises - educational customers, is gaining strength, targeted training of engineering personnel is developing. World-scale manufacturer's expansion on Russian markets demands the international quality of engineering training from universities, encourages them to interact with research organizations, initiates the development of twinning projects, and gives impetus to the development of training directly at enterprises.

- At the regional level, the conditions for the development of inter-university cooperation and research and educational cooperation are being formed. Along with this, increased competition in the Russian and international educational markets raises the issue of increasing the competitiveness of technical universities. Its primary factors are innovative educational activities and the ability of universities to participate in the development of the national innovation system.

- At the national level, the system of Russian universities is being adapted to the international requirements for the quality of engineers' training, to the level of competence of graduates, to technical equipment and educational and methodological support of the educational process. Of course, the leading role in this process belongs to technical universities, which should preserve and enhance the research and production potential of the Russian economy.

- At the international level, the globalization of the educational system is a kind of response to integration processes in the global economy, the formation of a common information space, and international labor migration. For Russian technical universities, the globalization of education provides the opportunity to act within the framework of the spatial-knowledge paradigm of social-and-economic development. This means that higher technical education, due to its applied nature, becomes an important factor in production and brings its owner a guaranteed income, regardless the particular country in which the engineer works.

Thus, Russian engineering universities involved in training personnel for the mining industry are facing today two fundamentally new challenges of international integration [67].

On the one hand, the globalization of the educational sphere as a response to the globalization of the economy makes mining education unitary, presenting similar requirements for the training of engineers in different countries. This is facilitated by the use of similar equipment and technologies, methods of management and production at mining enterprises in Russia, countries of Eastern and Western Europe, North and South America, Africa, Australia, China and others. This gives universities in different countries new incentives for the integration of scientific and educational activities, implementation of joint projects to improve the quality of higher mining education.

On the other hand, on the way to integration of Russian technical universities into the global educational system involved in the training of mining engineers, there are problems that reduce their competitiveness in the global educational market. These problems are associated with the long isolation of Soviet and Russian higher education from the world standards, the degradation of university science during the reform period, the marginalization of pedagogical work and the loss of its social prestige, the noninnovativeness of the Russian economy. As a result, many universities of a technical profile are engaged in survival on the educational market, and do not have the human, financial, material and technical resources in order to become the flagships of the innovation process development in industry.

Along with this, in Russia in training of mining engineers, the internal university 
opportunities for integration into the global educational space are not sufficiently realized, and diffusion of the latest technological innovations in the industry, professional language training, international student exchange with leading mining education centers in the USA, France, Germany, China are developing slowly.

\section{Results and Discussion}

The fact that most Russian universities that train mining engineers are not yet able to give an adequate answer to the latest challenges, hinders their entry into the place of national innovation centers, weakens their position in world university rankings, and makes it difficult to meet international requirements.

Therefore, it is necessary to create conditions conducive to the integration of Russian technical universities in the international environment of higher mining education. These conditions are the determinants of the integration process, and belong not only to the external processes (accession to the Bologna Agreements, international student exchange and training of foreign students). The starting point should be the introduction of international requirements for the very process of training students at a university. These determinants of integration of Russian universities into the international system of mining education related to the educational process itself include innovative, interactive forms of organization, as well as the development of its language competencies to the level that allows Russian graduates to compete on an equal conditions in the global labor market.

The innovative determinant includes the constant creative search for university teachers, familiarization with advanced examples of engineering and technology, the diffusion of new knowledge in the pedagogical community. In fact, the mining educational system must be a powerful block of training in innovations. An important role in this process should be played by innovative technologies of the training itself, in particular, the transition to new forms of lecture presentation of material (such as problematic and binary ones).

At the present stage of mining science development, a traditional lecture in terms of the speed of transmitting new information is inferior to scientific literature, the dissemination of experience in introducing new equipment and technologies in the mining professional community, patenting of inventions and diffusion of innovations in production. Therefore, the traditional form of a lecture - a uniform presentation of information by a teacher should give way to lectures involving students in a collective interaction with the teacher and with each other, in discussing the problems and prospects of introducing innovations into mining processes.

For example, during a problem lecture, the teacher and students are in an active scientific and cognitive position, if the lecture is in the form of a living dialogue. The subject of such a dialogue can be a discussion of the effect of introducing innovations, replacing obsolete equipment, and using new progressive forms of organization of production.

Thus, for students of mining specialty of the open pit mining specialization, issues for a lecture discussion today may be the tasks of improving the environmental friendliness of mining and cleaning of polluted water bodies, increasing productivity of equipment and improving raw material's quality.

The teacher, asking the students questions and finding answers together with them, brings them out for discussion to the entire audience. In response, students develop engineering thinking, show responsibility and uphold their point of view. The main organizing role in conducting a problematic dialogue lecture is played by the teacher, since the active study of the innovation process in the industry largely depends on his ability to conduct a discussion and build interaction with students.

Another example of learning technology, which implements the principles of 
problematicity and dialogue, is a binary lecture. It is the work of two teachers, simultaneously giving a lecture on the same topic and interacting on problem-organized material with each other and with the audience. In the dialogue between teachers and students, the problem is formulated the situation is analyzed, hypotheses are put forward, their proof or refutation is made, contradictions are resolved, solutions are found. To train mining engineers today, it is important to involve practitioners in educational activities. It is they who, first of all, are able to convey to students the horizons of innovation in the mining industry, the problems and prospects of introducing innovations in specific enterprises, and enhance their opinion.

\section{Conclusion}

Summing up, it should be emphasized that the use of innovative, interactive teaching methods in training mining students in Russian universities is designed not only to accelerate their integration into the international educational and cultural space, but also to improve the quality of Russian mining education. In the context of the expanding influence of Russian companies on international markets for raw materials, this should contribute to increasing national competitiveness in general.

\section{References}

1. O. V. Zhironkina, Economics and Innovation Management, 2, 24-32 (2017) DOI: 10.26730/2587-5574-2017-2-24-32

2. M.A. Klimovich, M.A. Gasanov, Economics and Innovation Management, 2, 8-17 (2019) DOI: 10.26730/2587-5574-2019-2-8-17

3. T. Snegireva, G. Kayachev, A. Falaleev, S. Kurgansky, E3S Web Conf., 134, 03014 (2019)

4. N. Zaruba, T. Fraltsova, T. Snegireva, E3S Web Conf., 21, 04028 (2017)

5. N. Kudrevatykh, T. Snegireva, A. Tselischeva, E3S Web Conf., 15, 04006 (2017)

6. S. Zhironkin, S. Demchenko, G. Kayachev, E. Taran, O. Zhironkina, E3S Web Conf., 105, 03008 (2019)

7. O. V. Zhironkina, E. V. Zolotova, Economics and Innovation Management, 4, 79-86 (2018) DOI: 10.26730/2587-5574-2018-4-79-86 